\title{
Rekonstruksi Wacana Poligami Berbasis Nalar Fiqhi Kontemporer
}

\author{
Halawati Halawati ${ }^{1}$, Mahdi Mahdi ${ }^{2}$, Zakirah Zakirah ${ }^{3}$, Muhammad Arsyam ${ }^{4}$
}

\author{
${ }^{1}$ Sekolah Tinggi Agama Islam (STAI) Darul Dakwah Wal-Irsyad (DDI) Kota Makassar, Indonesia. \\ Email: halawatihalwa99@gmail.com \\ ${ }^{2}$ Sekolah Tinggi Agama Islam (STAI) Darul Dakwah Wal-Irsyad (DDI) Kota Makassar, Indonesia. \\ Email: mahditimor88@gmail.com \\ ${ }^{3}$ Institut Agama Islam Negeri (IAIN) Sultan Amai Gorontalo, Indonesia \\ E-mail: zakirahira17@gmail.com \\ ${ }^{4}$ Sekolah Tinggi Agama Islam (STAI) Darul Dakwah Wal-Irsyad (DDI) Kota Makassar, Indonesia. \\ Email: arsyam0505@gmail.com
}

\begin{abstract}
Abstrak.
Poligami (ta'addud al-zaujah) jauh sebelum Islam lahir telah menjadi tradisi dan diperaktekkan oleh masyarakat jahiliyah. Sistem poligami pada masa pra Islam tidak dibatasi dengan jumlah tertentu. Poligami yang terjadi pada masa pra Islam nampak tidak menghargai perempuan dan cenderung hanya untuk memuaskan keinginan kaum laki-laki saja. Tidak ada larangan bagi para suami untuk memiliki beberapa orang istri bahkan mencapai ratusan. Islam lahir dalam keadaan poligami sudah mentradisi di kalangan bangsa-bangsa di permukaan bumi ini, tetapi tidak ada peraturan yang mengatur serta tidak ada batasannya. Islam sebagai agama Rammatan Lil 'Alamin berupaya untuk memberikan perbaikan atas budaya dan tradis yang tidak baik.
\end{abstract}

\section{Kata Kunci: Rekonstruksi, Poligami, Fiqhi Kontemporer.}

\section{A. Latar Belakang Masalah}

Islam memberikan batasan dan syarat-syarat yang cukup ketat dalam berpoligami, yaitu hanya dibatasi empat orang istri saja serta suami harus bisa berlaku adil diantara empat orang istrinya. Sebagaimna yang dijelaskan diatas, bahwa jauh sebelum kedatangan Nabi Muhammad SAW yang membawa Islam, Agama Samawi, umat terdahulu telah memperaktekkan poligami. Cukup banyak yang membuktikan kebenaran ini. Hal ini diakui oleh Musthafa al-Siba'i seperti dikatakannya " poligami itu sudah ada dikalangan bangsa-bangsa yang hidup pada zaman purba ...bangsa Yunani, Cina, India, Babylonia, Assyiria, Mesir dan lain-lain" ia menambahkan " poligami dikalangan mereka tak terbatas, sehingga mencapai 130 istri bagi seorang suami, malahan salah seorang raja cina ada yang mempunyai istri sebanyak 30.000 (tiga puluh ribu orang)orang."

Dalam agama yang lain seperti Yahudi dan Kristen juga membolehkan poligami. Sebagian Nabi- Nabi terdahulu juga ikut memperaktekkan poligami. Seperti Nabi 
Sulaiman mempunyai 700 (tujuh ratus istri). Nabi Musa juga tidak melarang Poligami tidak membatasi sampai berapapun.

Berdasarkan fakta sejarah diatas, poligami yang diperaktekkan oleh masyarakat pada masa sekarang merupakan kelanjutan syariat yang diamalkan oleh umat-umat terdahulu. Kenyataan ini menjadi bukti bahwa poligami sebenarnya bukanlah ajaran agama Islam. Bukan pula Nabi Muhammad yang memploporinya, seperti yang dituduhkan oleh Will Durran di dalam bukunya the Story of Civilization jilid pertama, sebagaimana dikutip Muthahhari " para teolog di zaman abad-abad pertengahan berpendapat bahwa muhammadlah yang memprakarsai poligami”.

Dengan demikian maka jelas pendapat yang dikemukakan oleh para orentalis tidak berdasarkan fakta sejarah yang valid. Islam mensyariatkan kembali peraktek poligami tidak hanya iktu-ikutan dan meneruskan syari'at umat terdahulu, akan tetapi lebih dari itu ingin memberikan sesuatu yang terbaik bagi kehidupan umat manusia di muka Bumi ini.

\section{B. Poligami Dalam Islam}

Kata poligami berasal dari bahasa Yunani yakni apolus artinya banyak dan kata gamos artinya perkawinan. Dari pengertian ini dapat dipahami bahwa yang dimaksud dengan poligami adalah suatu sistem perkawinan dimana seorang pria mengawini lebih dari seorang wanita dalam waktu yang bersamaan. Ada beberapa dalil yang dapat dijadikan sandaran tentang pembatasan poligami menjadi empat orang istri tidak membatasi : dianatara dalil dalil tersebut adalah :

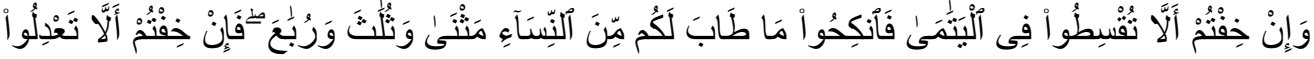

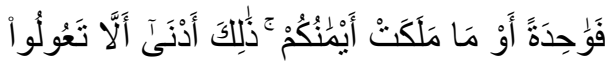

Artinya:

"Dan jika kamu takut tidak akan dapat berlaku adil terhadap (hak-hak) perempuan yang yatim (bilamana kamu mengawininya), Maka kawinilah wanita-wanita (lain) yang kamu senangi : dua, tiga atau empat. Kemudian jika kamu takut tidak akan dapat berlaku adil, Maka (kawinilah) seorang saja, atau budak-budak yang kamu miliki. yang demikian itu adalah lebih dekat kepada tidak berbuat aniaya".

Berdasarkan ayat diatas, manyoritas ulama berpendapat bahwa poligami tidak boleh lebih dari empat orang istri. Pendapat ini didasrkan atas apa yang pernah terjadi pada masa Rasulullah dimana Harist Bin Sabit yang mempunyai istri delapan orang dan ketika dia masuk Islam Nabi menyuruh memilih empat orang istri saja dan menceraikan 
yang lainnya. Sementara menurut golongan Syi'ah, poligami boleh lebih dari empat orang istri. Hal ini didasarkan pada Nabi Muhammad yang memiliki istri lebih dari empat orang. Oleh karena itu sebagai seorang istri tetap di butuhkan ketabahan hati serta kesabaran. Karena Bisa jadi di dunia orang yang sabar itu terlihat hina di mata orang lain, namun ia tetap mulia di sisi Allah dalam kehidupan dunianya ${ }^{1}$. Maka peranan suami tetap memberikan motivasi dalam mengarungi kehidupan di dunia dan akhirat kelak.

Syarat adil yang harus terpenuhi dalam poligami, secara sepintas bertentangan dengan surah An-Nisa ayat 129 tersebut diatas. Dalam ayat tersebut dijelaskan bahwa manusia tidak akan mampu berlaku adil diantara istri-istrimu.

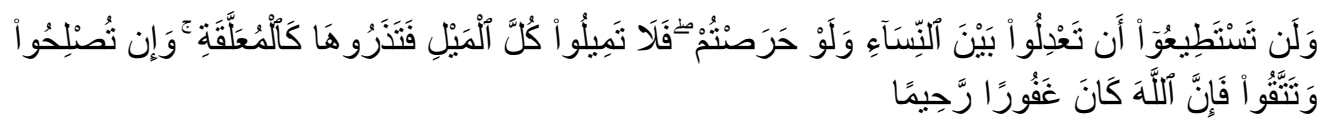

Artinya: "Dan kamu sekali-kali tidak akan dapat berlaku adil di antara istri- istri (mu), walaupun kamu sangat ingin berbuat demikian, karena itu janganlah kamu terlalu cenderung (kepada yang kamu cintai), sehingga kamu biarkan yang lain terkatungkatung. Dan jika kamu mengadakan perbaikan dan memelihara diri (dari kecurangan), maka sesungguhnya Allah Maha Pengampun lagi Maha Penyayang."

Menurut imam al-Qurthubi, yang dimaksud adil dalam surat an-Nisa'/4:3 adalah keharusan adil dalam hal kasih sayang, hubungan biologis, pergaulan dan pembagian nafkah. Pendapat al-Qurthubi dibantah oleh sebagian pendapat. Pendapat yang kedua mencoba mengklasifikasikan makna adil dalam dua ayat tersebut diatas.Yang dimaksud adil dalam konteks perkawinan adalah adil dalam hal-hal yang bersifat fisik-material. Sebab keadilan dalam hal inilah yang berada dalam bingkai kemampuan manusia. Oleh karena itu perlunya mengatur serta memberikan kepercayaan dengan sebaik-baiknya, contohnya salah satu indikasi keberhasilan seseorang dalam menjalankan manajerial terletak bagaimana memilih dan mempercayai orang lain ${ }^{2}$.

Jadi idealnya mesti yang harus dipahami jika seorang dalam mengarungi rumah tangga secara poligami memahami tata cara mengatur dalam memberikan nafkah secara lahir dan bathin. Untuk itulah upaya manajemen kebidupan secara pulgar dan antisipatif

\footnotetext{
${ }^{1}$ Arsyam, Muhammad, and Ibnu Hajar Sainuddin. "Meraih Surga dengan Sabar dan Syukur." h.3

${ }^{2}$ Arsyam, M. (2020). MANAJEMEN PENDIDIKAN ISLAM.
} 
secara Qur'ani adalah merupakan upaya dan langkah yang sangat tapat guna memperkecil kemungkinan terjadinya resiko (probabilaty of loss). ${ }^{3}$

Sementara adil dalam ayat kedua adalah adil dalam hal-hal yang bersifat maknawiyah seperti perasaan cinta yang berada di luar kemampuan manusia. Cinta yaitu mencintai kalimat yang agung ini serta semua ajaran dan konsekwensi yang terkandung didalamnya maka dia mencintai Allah dan Rasul-Nya dan mendahulukan kecintaan kepada keduanya atas semua kecintaan kepada yang lainnya serta melakukan semua syarat-syaratnya dan konsekwensinya ${ }^{4}$.

Pembagian keadilan menjadi material dan immaterial merupakan hasil dari perpaduan (al-jam'u wa al-taufĩq) dua ayat, yaitu al-Nisa' ayat 3 dan 129 yang secara dhahir terkesan kontradiktif. Indikasi dari perpaduan itu adalah ujung dari ayat 129 (falâ tamǐlû kulla al-maili...) yang merupakan amnesti ketuhanan (al-'afwu al-ilâhi) terhadap keharusan berbuat adil dalam hal-hal yang bersifat immaterial.

\section{Poligami dalam Pandangan Fiqh Kontemporer}

1. Poligami dalam Pandangan Syahrur Muhammad.

Syahrur dikenal sebagai tokoh pemikir muslim kontemporer yang banyak melakukan penafsiran terhadap al-Qur'ān. Teori Batas (nadzariyyah al-hudūd) menjadi teori handalnya dalam melakukan penafsiran terhadap setiap tema ayat terutama menyangkut kehidupan sosial umat Islam. Diantaranya adalah persoalan poligami. Dalam analisisnya Syahrur memulai dengan ayat berikut yang Artinya: "Dan jika kamu takut tidak akan dapat berlaku adil terhadap (hak-hak) perempuan yang yatim (bilamana kamu mengawininya), Maka kawinilah wanita-wanita (lain) yang kamu senangi : dua, tiga atau empat. Kemudian jika kamu takut tidak akan dapat berlaku adil, Maka (kawinilah) seorang saja, atau budak-budak yang kamu miliki. yang demikian itu adalah lebih dekat kepada tidak berbuat aniaya".

\footnotetext{
${ }^{3}$ Arsyam, M., \& Alwi, A. M. (2020). MANAJEMEN HIDUP DALAM PERSPEKTIF ALQUR'AN. h.2

${ }^{4}$ Sainuddin, I. H., S, Arsyam, M., \& Alwi, A. M. S. (2020, August 19). Pemahaman Makna Tauhid dan Dua Kalimat Syahadat. https://doi.org/10.31219/osf.io/g84vu
} 
Syahrur menganalisis ayat di atas dengan memunculkan dua batas (al-hadd), yaitu hadd fi al-kamm (secara kuantitas) dan hadd fi al-kayf (secara kualitas).

Pertama, secara kuantitas, ayat itu menjelaskan bahwa hadd al-adnâ atau jumlah minimal istri yang diperbolehkan syara' adalah satu, sebab tidak mungkin seseorang beristri separuh. Adapun al-hadd al-a'lā atau jumlah maksimum yang diperbolehkan adalah empat. Sebagaimana ditegaskan dalam ayat di atas, seseorang boleh beristri lebih dari seorang, yakni dua, tiga hingga empat orang.

Penyebutan satu persatu jumlah perempuan dalam ayat matsnā wa stulāsta wa rubā, menurut Syahrur, harus dipahami sebagai penyebutan bilangan bulat secara berurutan, karena itu tidak bisa dipahami $2+3+4$ yang berjumlah sembilan. Dengan demikian, melebihi dari jumlah tersebut berarti dia telah melanggar batasan-batasan (hudūd) yang telah ditetapkan oleh Allah. Pemahaman ini yang telah disepakati selama empat belas abad yang silam, tanpa memperhatikan konteks dan dalam kondisi bagaimana ayat tersebut memberikan batasan (hadd fi al-kayf).

Kedua, hadd fi al-kayf. Yang dimaksud di sini adalah apakah istri tersebut masih dalam kondisi bikr (perawan) atau tsayyib/armalah (janda)? Syahrur mengajak untuk melihat hadd fi al-kayf ini karena ayat yang termaktub dalam surat al-Nisa' ayat 03 tersebut memakai redaksi syarth. Karena itu, seolah-olah, menurut Syahrur, kalimatnya adalah : "Fankihǔ mâ thaba lakum min al-nisâ' matsnâ wa thulâtsâ wa rubâ' ..." dengan syarat kalau "wa in khiftum an lâ tuqsithū fi al-yatâmâ ...”. Dengan kata lain, untuk istri pertama tidak disyaratkan adanya hadd fi al-kayf, maka diperbolehkan perawan atau janda, sedangkan pada istri kedua, ketiga dan keempat dipersyaratkan dari armalah (janda yang mempunyi anak yatim). Maka seorang suami yang bermaksud beristri lebih dari satu itu akan menanggung istri dan anak-anaknya yang yatim. Hal ini, menurut Syahrur, akan sesuai dengan pengertian 'adl yang harus terdiri dari dua sisi, yaitu adil kepada anak-anaknya dari istri pertama dengan anak-anak yatim dari istri-istri berikutnya. 


\section{Poligami dalam pandangan Nasr hamid Abu Zayd}

Sebagaimana Muhammad Syahrur, Nasr Hamid Abu Zaid adalah salah seorang pemikir kontemporer yang juga concern di bidang Islamic studies, maka isu mengenai poligami tidak luput dari perhatiannya. Dalam melakukan analisis, Abu Zayd juga kembali pada surat al-Nisā' ayat 3. Analisis terhadap persoalan ini dia lakukan melalui tiga langkah:

Pertama, Konteks dari teks itu sendiri. Dia memulai pembahasan ini dengan mempertanyakan terabaikannya makna dari ayat "atau budak-budak perempuan yang kamu miliki" pada potongan ayat tersebut. Yang ia maksudkan adalah, bahwa praktek hukum memiliki tawanan perang atau budak perempuan sebagai selir yang boleh digauli dalam wacana Islam telah hilang selamanya, sementara pada sisi yang lain poligami terus menerus dipertahankan. Padahal, menurutnya, hal itu telah ditetapkan oleh teks yang sama tingkat kejelasan dan ketegasannya.

Kedua, Meletakkan teks dalam konteks al-Quran secara keseluruhan. Tujuan dari langkah ini, bagi Nashr Hamid, adalah untuk mengungkapkan suatu dimensi makna yang tersembunyi (al-maskut 'anhu) atau "yang tak terkatakan". Teks al-Quran sendiri menyarankan untuk hanya memiliki seorang istri jika suami khawatir tidak bisa berbuat adil; "jika kamu takut tidak akan bisa berbuat adil (terhadap mereka) maka seorang saja”. Dalam ayat lain ditegaskan yang Artinya: "Dan kamu sekali-kali tidak akan dapat berlaku adil di antara istri- istri (mu), walaupun kamu sangat ingin berbuat demikian." Dengan adanya dukungan ayat tersebut, tegas Abu Zaid, bersikap adil terhadap para istri adalah tidak mungkin dilakukan. Dalam konteks poligami, keadilan adalah satu hal yang prinsip (mabda'). Bolehnya memiliki istri lebih dari satu hingga empat orang istri adalah sebuah hukum, namun hukum tidak bisa dijadikan dasar jika bertentangan dengan prinsip dasar ditegakkannya hukum tersebut. Karena itu, jika antara hokum dan mabda' saling bertentang maka hukum tidak bisa dipertahankan.

Ketiga, dengan mendasarkan secara logis pada dua langkah di atas, Abu Zayd mengusulkan sebuah pembaharuan hukum Islam. (dalam hukum Islam klasik, poligami 
diklasisifikasikan dalam "hal-hal yang diperbolehkan" (al-mubahah). Pembolehan poligami dalam realitas merupakan "penyempitan" dan transisi terhadap poligami yang lebih luas dan mendahului hukumnya, karena itu tema pembolehan (ibahah), menurut Abu Zayd, tidaklah sesuai karena pembolehan terkait dengan hal yang tidak diperbolehkan oleh teks. Sementara pembolehan poligami dalam al-Quran pada hakikatnya adalah sebuah pembatasan dari poligami yang tidak terbatas yang telah dipraktekkan di masa pra Islam.

Dengan demikian, Abu Zayd mengharamkan poligami secara multak dengan memberikan tiga fokus pembahasan di atas tanpa memberi dispensasi hukum meski dalam kondisi darurat. Hukum ini diambil dari maghzā (signifikansi) ayat-ayat al-Qur'ān yang saling terkait mengenai ketentuan hukum poligami.

\section{Poligami Dalam Kompilasi Hukum Islam Poligami}

Dalam KHI diatur dalam pasal 55 (1) Beristri lebih dari satu orang pada waktu bersamaan terbatas hanya sampai empat orang istri. (2) Syarat utama beristri lebih dari seorang, suami harus mampu berlaku adil terhadap istri-istri dan anak-anaknya (3) Apabila syarat utama yang disebut pada ayat (2) tidak mungkin dipenuhi, suami dilarang beristri lebih dari seorang.

Pasal 56 (1) Suami yang hendak beristri lebih dari satu orang harus mendapat izin dari pengadilan agama. (2) Pengajuan permohonan izin dimaksud pada ayat (1) dilakukan menurut tata cara sebagaimana diatur dalam Bab VIII peraturan pemerintah No. 9 tahun 1975. (3) Perkawinan yang dilakukan dengan istri kedua, ketiga atau keempat tanpa izin dari pengadilan agama tidak mempunyai kekuatan hukum.

Pasal 57 Pengadilan agama hanya akan memberi izin kepada seorang suami yang akan beristri lebih dari seorang apabila:

a. Istri tidak dapat menjalankan kewajiban sebagai istri.

b. Mendapat cacat badan atau penyakit yang tidak dapat disembuhkan

c. Istri tidak dapat melahirkan keturunan 


\section{Kesimpulan}

Dari beberapa uraian diatas dapat disimpulkan bahwa manoritas dari kalangan ulama klasik memperbolehkan poligami selama tidak keluar dari batas-batas atau aturanaturan yang telah ditetapkan dalam al-Quran. Sementara ulama kontemporer dalam merespon persoalan poligami sangat beragam karena berangkat dari cara pandang yang berbeda dalam menafsiri ayat-ayat poligami. sebagaimana pendapat yang dikemukakan oleh Nasr Hamid bahwa poligami sudah tidak bisa diperaktekkan lagi pada masa sekarang. Sementara menurut Syahrur poligami poligami diperbolehkan dengan syarat harus memenuhi syarat-syarat yang telah ditentukan.

Dalam hukum perkawinan di Indonesia persolan poligami semakin diperketat hukumnya. Hal ini dimaksudkan untuk memberi perlindungan terhadap perempuan (istri). Syarat yang harus dipenuhi bagi seseorang yang hendak berpoligami diantaranya adalah: (1) Suami harus mendapat izin dari istri pertama dan pengadilan Agama. (2). Ketika istri tidak dapat menjalankan kewajiban sebagai istri. Dan Istri mendapat cacat badan atau penyakit yang tidak dapat disembuhkan. Serta istri tidak dapat melahirkan keturunan.

\section{E. Daftar Pustaka}

Arsyam, M. (2020). MANAJEMEN PENDIDIKAN ISLAM.

Arsyam, M., \& Alwi, A. M. (2020). MANAJEMEN HIDUP DALAM PERSPEKTIF AL-QUR'AN.

Arsyam, M., \& Sainuddin, I. H. Meraih Surga dengan Sabar dan Syukur.

Anshari, Zakariya, Fathu Al-Wahhab, Bairut: Dar- Al-Fikr, 925, Juz II

Ali, M. Hasan, Masail Fiqhiyah Al-Haditsah, Masalah-Masalah Kontemporer Hukum Islam, Jakarta: PT Raja Grafindo Persada, 1998

Baidan, Nasaruddin, Tafsir Bi Al-Ra'yi, Yogyakarta: Pustaka Pelajar, 1999.

Chuzaimah dan Hafiz Anshary (Ed), Problematika Hukum Islam Kontemporer, (Jakarta: PT Pustaka Firdaus bekerjasama dengan Lsik, 1996

Derajat, Zakiah, Ilmu Fiqh, Yogyakarta: PT Dana Bhakti Wakaf, 1995. 
Haikal, Abuduttawab, Rahasia Perkawinan Rasulullah, Poligami Dalam Islam Vs Monogamy Barat Jakarta: CV Pedoman Ilmu Jaya, 1993.

Katsir, Ibnu, Tafsir Al-Quan Al-'Adim, Bairut: Maktabah An-Nur Al'ilmiyah, tt, juz I Kompilsi Hukum Islam, (Jakarta: Departemen Agama RI, 2001

Nasution, Khairuddin, Riba Dan Poligami Yogyakarta: Pustaka Pelajar dengan ACAdeMIA,1996.Nur Ichwan, A New Horizon in Qur'anic Hermeneutic

Nasr Hamid Abu Zayd's Contribution to Critical Qur'anic Scholarship, MA thesis in Islamic Studies, Leiden University the Netherlans, 1999

Sainuddin, I. H., S, Arsyam, M., \& Alwi, A. M. S. (2020, August 19). Pemahaman Makna Tauhid dan Dua Kalimat Syahadat. https://doi.org/10.31219/osf.io/g84vu

Shabuni, Muhammad Aly, Rawai' Al-Bayan Tafsir Ayat Al-Ahkam, Bairut: Dar AlKutub Al-Islamiyah, $\mathrm{tt}$

Siba'y, Musthafa, Almar-Atu Bainal Fiqhi Wal Qanun, Alih Bahasa Chadidjah Nasution, Wanita Diantara Hukum Islam Dan Perundang-Undangan, Jakarta: bulanbintang, 1977

Sosroatmodjo Arso dan Wasit Aulawi, Perkawinan di indonesia, Jakarta: Bulan Bintang, 1978

Syahrur, Muhammad, Al-Kitab Wa-Al-Quran: Qirat Mu'ashirah, Alih Bahasa Sahiron Syamsuddin dan Burhanuddin Dzikri, Prinsip-Dan Dasar Hermeneutika Hukum Islam Kontemporer, Yogyakarta: eLSAQ Press, 2007 